\title{
A Comparison of Other World Perceptions by Near-Death Experiencers and by the Marian Visionaries of Medjugorje
}

\author{
Craig R. Lundahl, Ph.D. \\ Western New Mexico University
}

\begin{abstract}
Near-death research has identified another world that consists of two divisions: Cities of Light and a Realm of Bewildered Spirits. In 1981, the apparition of Mary, the mother of Jesus, appeared to six young people in the village of Medjugorje, Croatia. These young visionaries were shown Heaven, Purgatory, and Hell in visions that were like watching a movie. Two of the visionaries were also physically transported to see these realms. A comparison of their observations of the other world with those of near-death experiencers (NDErs) shows a close similarity between them. The visionaries' observations provide some corroboration for the City of Light and Realm of the Bewildered Spirits elements of the NDE and suggest the possibility of a third division called Hell. Further study of frightening NDEs may reveal whether or not those NDErs who travel to a less than heavenly realm may be going to two separate places instead of one.
\end{abstract}

In 1977, Raymond Moody, the founder of modern near-death studies, identified "cities of light" and "a realm of bewildered spirits" as less common elements of the near-death experience (NDE) that normally occur in near-death encounters of extreme duration. Moody found that his subjects described the City of Light as a "heavenly" realm (1977, p. 15). The Realm of Bewildered Spirits appeared to contain dulled beings who were trapped in an unfortunate state of existence (Moody, 1977, p. 18).

I first used information from NDEs to describe in some detail the social system and the physical dimension of the City of Light in the

Craig R. Lundahl, Ph.D., is Professor Emeritus of Sociology and Business Administration and Chair Emeritus of the Department of Social Sciences at Western New Mexico University. 
perceived other world (Lundahl, 1981-82). I briefly described the social structure, social interaction, social stratification, social control, socialization activities, buildings, landscapes, and vegetation in the other world of the NDE. Other researchers who had documented NDE accounts that gave some information on the physical environment in the City of Light included Ray Canning (Lundahl, 1981-82), Karlis Osis and Erlendur Haraldsson (1977), Kenneth Ring (1980), and Michael Sabom and Sarah Kreutziger (Sabom, 1982). In 1993, Harold Widdison and I described the social positions of inhabitants in the City of Light as reported by a limited number of Mormon NDErs and provided more detail about the physical environment in the City of Light (Lundahl and Widdison, 1993; Widdison and Lundahl, 1993). The most detailed description of the social and physical aspects of the City of Light put forth to date was published in our book The Eternal Journey (Lundahl and Widdison, 1997).

Widdison and I found that NDErs describe life after death as consisting of two major divisions with the possibility of a third division. One of the major divisions was the Cities of Light with their countrysides. This division contains countrysides with beautiful landscapes of mountains, hills, valleys, fields of golden grass and flowers, meadows, paths, trails, lanes, roads, great forests, brooks, streams, rivers, ponds, and lakes. The plant life includes grass, flowers, trees of all kinds, shrubs, and vegetable and flower gardens. There is a variety of animal life and insects such as butterflies and bees. Buildings such as houses and some larger buildings are also found in the countrysides (Lundahl and Widdison, 1997, pp. 140-153).

The beautiful gardens, flowers, shrubs, and trees in the Cities of Light perfectly complement their physical structures, which include walls, gates, streets, houses, and various buildings with magnificent interiors and furniture (Lundahl and Widdison, 1997, pp. 154-170). The cities in this first division emanate light. For example, four NDErs described it this way:

(My guide) next led me to a city. It was a city of light. It was similar to cities on earth in that there were buildings and paths, but the buildings and paths appeared to be built of materials which we consider precious on earth. They looked like marble, and gold, and silver, and other bright materials, only they were different. The buildings and streets seemed to have a sheen and to glow. The entire scene was one of indescribable beauty.... There was a feeling of love and peace.

After soaring for a while, she (the angel) sat me down on a street in a fabulous city of buildings made of glittering gold and silver and 
beautiful trees. A beautiful light was everywhere-glowing but not bright enough to make me squint my eyes.

... and then I saw, infinitely far off, far too distant to be visible with any kind of sight I knew of . . . a city. A glowing, seemingly endless city, bright enough to be seen over all the unimaginable distance between. The brightness seemed to shine from the very walls and streets of this place, and from the beings which I could now discern moving about within it. In fact, the city and everything in it seemed to be made of light...

The beauty of the countryside was incredible but even it could not compare with the splendor of the city because of the glow. (Lundahl and Widdison, 1997, pp. 155-156)

There are several cities built of light that appear to be on different levels with each city being more grand than the last one, but all far superior to any city on earth (Lundahl and Widdison, 1997, p. 170).

All the Cities of Light are characterized by intense levels of activity. All people in these Cities of Light have something meaningful to do, a job or assigned responsibility that fits into the overall operation of the city that they willingly perform. Everyone seems to be content and happy as they actively pursue their various activities. In general, most of the activities revolve around the family, which is the basic social unit in the other world (Lundahl and Widdison, 1997, pp. 171-192).

The second major division is the Realm of Bewildered Spirits. Documentation on this division of the other world in NDEs is found in the work of Moody (1977), Maurice Rawlings (1978, 1993), Margot Grey (1985), George Gallup and William Proctor (1982), Bruce Greyson and Nancy Evans Bush (1992), and Arvin Gibson (1996). Widdison and I described this division as a dark, gloomy, and hostile environment where millions of unhappy and wicked people who are gray, bewildered, confused, miserable, anguished, dreary, angry and do not seem to communicate much, are confined until they can solve whatever problem they have that appears to be keeping them there (1997, pp. 222-238). For example one NDEr described this division as follows:

The next thing I remember is being sucked down a vast black vortex like a whirlpool and I found myself in a place that I can only describe as being like Dante's Inferno. I saw a lot of other people who seemed gray and dreary and there was a musty smell of decay. There was an overwhelming feeling of loneliness about the place. (Grey, 1985, p. 64)

The possibility of a third division called "hell" is suggested by the NDE account of Don Brubaker (Lundahl and Widdison, 1997, pp. 229233). However, no study has yet provided data that establish whether 
such a hellish realm exists, and if so, what might distinguish between it and the Realm of the Bewildered Spirits.

The purpose of this article is to compare the perceptions of the other world found in NDEs with those of the Marian visionaries of Medjugorje, Croatia. This examination, although limited, can serve as an independent confirmation of the other world by viewers who reportedly have seen it while not near death.

\section{Visions of the Other World in Medjugorje}

On June 24, 1981, six years after the founding of the field of neardeath studies, the apparition of Mary, the mother of Jesus, appeared to two young girls, Mirjana Dragicevic and Ivanka Ivankovic, outside the village of Medjugorje in the central part of the former Yugoslavia. The next day they returned to the same place with three other teenagers named Vicka Ivankovic, Ivan Dragicevic, and Marija Pavlovic, and a little boy named Jacov Colo. That day they all saw the apparition and heard her speak and identify herself as the Blessed Mother. She still appears to all the visionaries, and to four of these six visionaries she continues to appear every day (Connell, 1990, pp. 1-2).

All of the visionaries are of the Catholic faith and describe Heaven, Purgatory, and Hell as the divisions of the other world. Each of the visionaries was shown Heaven, Purgatory, and Hell in visions that were like watching a movie, except for Mirjana Dragicevic and Ivanka Ivankovic who did not see Hell because they did not want to see it. Vicka Ivankovic and Colo not only had visions, but were also transported bodily to see these realms, during which they reportedly disappeared for twenty minutes (Brown, 1992, pp. 217-219).

Mirjana Dragicevic noticed that the people in Heaven had bodies, were about 30 years of age and dressed in clothing like that Jesus wore, radiated a type of inner light, and were immensely happy. She saw people walking in a beautiful park. She said Heaven had trees, meadows, and a light that is brilliant, and said that "Heaven is beautiful beyond any possible comparison with anything I know of on the earth" (Connell, 1990, pp. 25-26). Ivanka Ivankovic also said that Heaven was a very beautiful place, and also noticed that people had bodies and wore robes, and that everyone was filled with an unexplainable happiness (Connell, 1990, p. 38). Vicka Ivankovic said Heaven was vast and had a brilliant light. She and Colo saw people dressed in variously colored robes who were walking, praying, and singing, and who were 
very happy (Connell, 1990, p. 62). Ivan Dragicevic also said people in Heaven are happy (Connell, 1990, p. 87).

Purgatory is only darkness according to Ivanka Ivankovic (Connell, 1990, p. 39). Vicka Ivankovic said Purgatory is large and misty with gray fog where people could be heard weeping, moaning, and trembling, and where people are extremely lonely (Connell, 1990, pp. 65-66). Pavlovic also described Purgatory as a large, foggy, gray, and misty place, and said there are people there but they cannot be seen (Connell, 1990, p. 119).

Two of the visionaries did not see Hell and the other visionaries, except for two, do not talk about this realm. Vicka Ivankovic said that there are many people in this realm. She described Hell as a location with a great fire at its center where people enter and emerge no longer possessing a human shape: they go into the fire naked and come out with horrifically blackened skin (Brown, 1992, p. 219). According to her, the people in Hell are full of rage, horrible, ugly, and angry (Connell, 1990, pp. 63-64). Pavlovic also described this realm as a large space with many people and a big sea of fire in the middle (Connell, 1990, p. 120).

Generally, the Medjugorje visionaries describe Heaven as a brilliantly lit and most beautiful place with trees, meadows, and parks unlike anything on earth that are filled with people about 30 years of age wearing variously colored robes who radiate an inner light and are immensely happy. They are seen walking, praying, and singing. The visionaries said Purgatory is a large, foggy, gray, and misty place filled with lonely people who are weeping and moaning that they could not see. Hell is a large space with a big sea of fire in the middle occupied by raging, horrible, and angry people who have grotesque nonhuman shapes according to two of the visionaries.

\section{A Comparison of Other World Perceptions by NDErs and by the Marian Visionaries of Medjugorje}

In order to compare the perceived other world in NDEs and in the visions and bodily visits by the Marian visionaries in Medjugorje, I will use basic features of the divisions in the other world derived primarily from Widdison's and my descriptions of the other world as revealed in NDEs.

The basic features of the City of Light are the world of light and preternatural beauty, vegetation, and physical structures, inhabited by content and happy people who emanate light. The basic features 
of the Realm of Bewildered Spirits are the world of darkness and fog, the damp, musty, and lonely environment, and earthen structures and walls, inhabited by bewildered, confused, miserable, anguished, dreary, angry, and unhappy people who have a gray or dark appearances. A division and the features for Hell, a realm described by the Marian visionaries, have not been established or delineated in near-death studies.

The Table 1 compares NDE perceptions of the other world divisions with those of the Marian visionaries of Medjugorje on each of the basic features. The comparative term used by the visionaries for City of Light is "Heaven" and that for the Realm of Bewildered Spirits is "Purgatory," while the term "Hell" to denote a separate division is used only by the visionaries.

An examination of these divisions and features shows that the visionaries in their brief glimpses of the other world did not see any physical structures in the City of Light, as did some NDErs. Another difference in the observations of NDErs and the Marian visionaries is found in the Realm of Bewildered Spirits, where NDErs often describe seeing people who appear to be gray or dark, whereas the visionaries did not see any people but did hear them. For this reason the Table 1 shows a qualified yes under the Marian visionaries next to the people found in the Realm of Bewildered Spirits, since both the NDErs and the Visionaries appear to agree that people are unhappy in this division of the other world.

What is particularly interesting in this comparison is the fact that the Marian visionaries were shown or taken to a realm in the other world that they identified as Hell, a realm that to date has not been well delineated in near-death studies. The visionaries say this realm has fire, a particular environment, and strange people. They do not mention any particular structures in this realm.

\section{Conclusion}

Despite the fact that the Marian visionaries of Medjugorje were very young and had only brief and limited glimpses of the other world and did not see with any detail (Connell, 1990, p. 136), they still had observations that closely corresponded with those of NDErs.

The visionaries' observations in the other world suggest the possibility of a third division or realm, of which near-death researchers are not yet cognizant. These observations lend support for further study of frightening NDEs to determine whether or not those NDErs who travel to a less than heavenly realm may be going to two separate places instead of one. Various frightening NDE cases suggest this might be a 


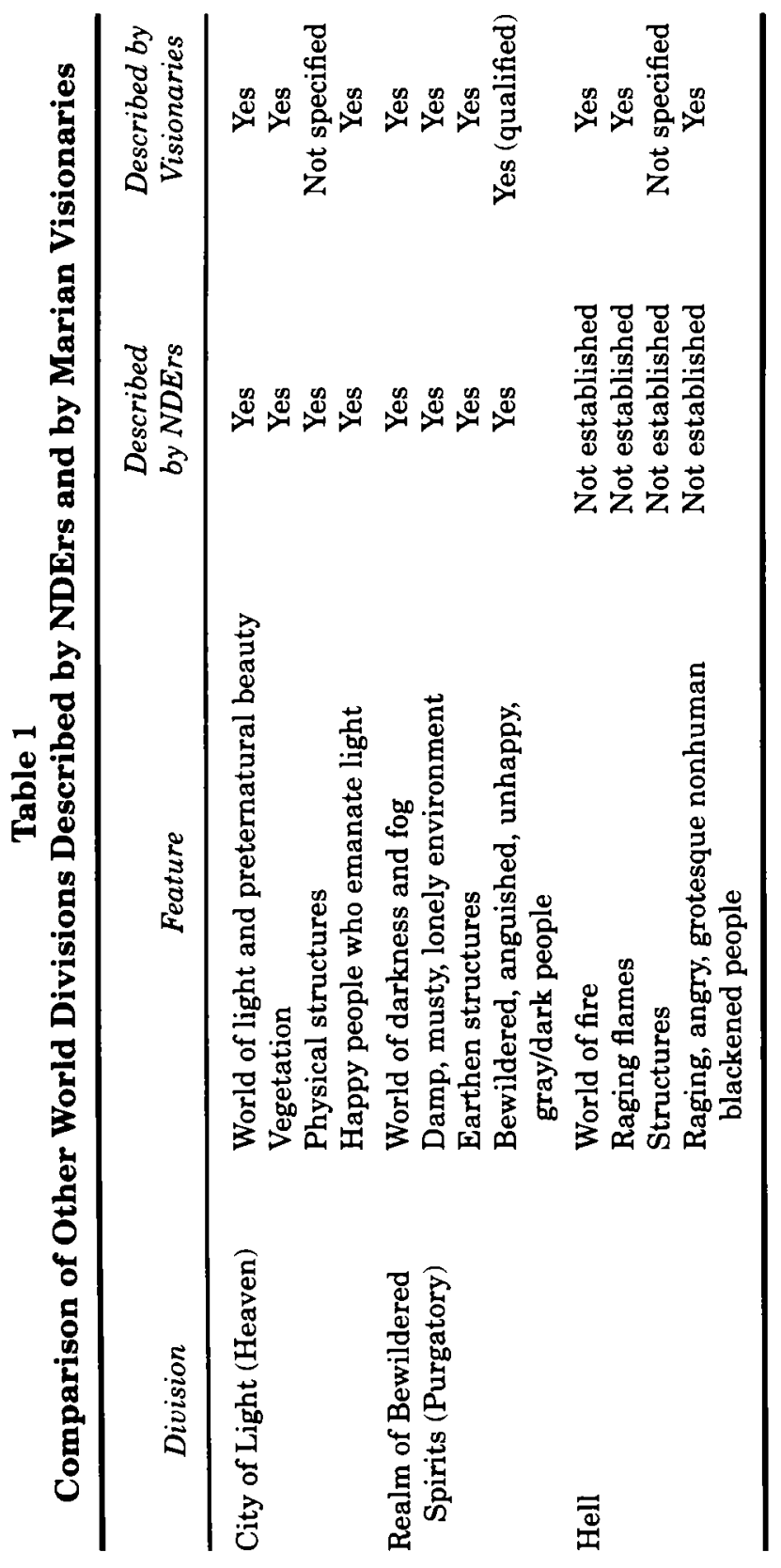


possibility. However, in most of these cases the NDErs feel they are in what they call "hell" just because of the foreboding nature of the experience, when in fact it may be what the visionaries saw as Purgatory. A beginning point in such a study might be to analyze a number of frightening NDE cases in terms of the basic features of the Realm of Bewildered Spirits and those of Hell as identified by the Marian visionaries. If features of both divisions are described by those NDErs who experience a less than heavenly realm, then more specific characteristics of each division could be identified.

If the observations of the Marian visionaries do nothing else, at least they provide some corroboration for the City of Light and Realm of the Bewildered Spirits elements of the NDE from a source other than NDEs. Father Slavko Barbaric, the visionaries' spiritual director, said, "I think they were permitted to see... so that they could witness to us.... So they are naive witnesses-'we know it exists, we saw it" (Connell, 1990, pp. 136-137). Is that not the same message NDErs who have seen the other world have been trying to give?

\section{References}

Brown, M. H. (1992). The final hour. Milford, OH: Faith Publishing Company.

Connell, J. (1990). Queen of the Cosmos. Orleans, MA: Paraclete Press.

Gallup, G., and Proctor, W. (1982). Adventures in immortality: A look beyond the threshold of death. New York, NY: McGraw-Hill.

Gibson, A. S. (1996). Commentary on "Frightening near-death experiences." Journal of Near-Death Studies, 15, 141-148.

Grey, M. (1985). Return from death: An exploration of the near-death experience. London, England: Arkana.

Greyson, B., and Bush, N. E. (1992). Distressing near-death experiences. Psychiatry, 55, 95-110.

Lundahl, C. R. (1981-82). The perceived other world in Mormon near-death experiences: A social and physical description. Omega, 12, 319-327.

Lundahl, C. R., and Widdison, H. A. (1993). Social positions in the City of Light. Journal of Near-Death Studies, 11, 231-238.

Lundahl, C. R., and Widdison, H. A. (1997). The eternal journey: How near-death experiences illuminate our earthly lives. New York, NY: Warner Books.

Moody, R. A. (1977). Reflections on life after life. St. Simon's Island, GA: Mockingbird Books.

Osis, K., and Haraldsson, E. (1977). At the hour of death. New York, NY: Avon.

Rawlings, M. (1978). Beyond death's door. Nashville, TN: Thomas Nelson.

Rawlings, M. (1993). To hell and back: Life after death-Startling new evidence. Nashville, TN: Thomas Nelson.

Ring, K. (1980). Life at death: A scientific investigation of the near-death experience. New York, NY: Coward, McCann and Geoghegan.

Sabom, M. B. (1982). Recollections of death: A medical investigation. New York, NY: Harper and Row.

Widdison, H. A., and Lundahl, C. R. (1993). The physical environment in the City of Light. Journal of Near-Death Studies, 11, 239-246 